\title{
IDENTIFIKASI BAHAYA PSIKOSOSIAL PADA BURUH WANITA DI PABRIK KARET
}

\section{Desheila Andarini ${ }^{1}$, Pacu Putra ${ }^{2}$, Maya Puspasari ${ }^{3}$, Ani Nidia Listianti ${ }^{4}$ Sasviana Putri $^{5}$}

1,2,3,4,5 Program Studi Ilmu Kesehatan Masyarakat Fakultas Kesehatan Masyarakat Universitas Sriwijaya, Jl. Raya Palembang - Prabumulih, Indralaya, Sumatera Selatan Email: 1desheila_andarini@ fkm.unsri.ac.id

\section{Abstrak}

Pekerja informal berjumlah 1,8 miliar (60\% dari angkatan kerja global) dan menghadapi insekuritas dan stres kerja yang lebih besar daripada pekerja yang dipekerjakan secara formal, dan mereka tidak memiliki akses terhadap pelayanan kesehatan yang terjangkau dan perawatan kesehatan yang berkualitas. Buruh perempuan merupakan salah satu komunitas yang rentan terhadap masalah kesehatan. Buruh perempuan yang telah menikah dan punya anak memiliki peran dan tanggung jawab yang lebih berat daripada wanita single. Ketidakpuasan dan insekuritas terhadap lingkungan pekerjaan yang merupakan bahaya psikososial dapat berdampak negatif pada kesehatan buruh tersebut. Tujuan penelitian ini adalah untuk menganalisis identifikasi bahaya psikososial pada buruh wanita di pabrik karet. Informan dalam penelitian ini adalah pekerja buruh wanita di pabrik karet sebanyak delapan orang. Metode penelitian adalah kualitatif dengan melakukan identifikasi terhadap risiko bahaya psikososial pada buruh wanita di pabrik karet. Hasil penelitian diketahui bahwa bahaya psikososial yang teridentifikasi diantaranya adalah risiko stress di tempat kerja berupa hubungan interpersonal dan beban kerja. Dengan teridentifikasi risiko psikososial di tempat kerja maka perusahaan perlu menerapkan tindakan pencegahan agar buruh wanita mendapatkan perlindungan di tempat kerja.

Kata kunci: Buruh perempuan, hazard, psikososial.

\begin{abstract}
Informal workers account for 1.8 billion (60\% of the global workforce) and face greater employment insecurity and stress than workers who are formally employed, and they do not have access to affordable health services and quality health care. Female workers are one community that is vulnerable to health problems. Married female workers and children have more severe roles and responsibilities than single women. Dissatisfaction and insecurity towards the work environment which is a psychosocial hazard can have a negative impact on the health of these workers. The purpose of this study was to analyze the identification of psychosocial hazards in female workers in rubber factories. Informants in this study were eight female workers in rubber factories. The research method is qualitative by identifying the risk of psychosocial hazards for female workers in
\end{abstract}


rubber factories. The results of the study revealed that the psychosocial hazards identified included stress risk in the workplace that is interpersonal relationship and occupational workload. By identifying psychosocial risks in the workplace, companies need to implement preventative measures so that women workers get protection in the workplace.

Keywords: Woman labour, hazard, psychosocial,

\section{PENDAHULUAN}

Risiko psikososial untuk buruh dapat dipengaruhi oleh dua faktor: tuntutan aktual pekerjaan mereka, termasuk pengaruh lingkungan kerja sosial, dan ketersediaan atau kekurangan sumber daya untuk menangani tuntutan ini dengan sukses. Sumber daya dapat membantu orang menemukan solusi untuk masalah kerja, dan juga membantu memenuhi kebutuhan psikologis individu yang menimbulkan kepuasan kerja dan kesejahteraan (seperti rasa prestasi, penghargaan dan penghargaan). Masalah psikososial di tempat kerja yang dapat mempengaruhi kesehatan dan kesejahteraan mencakup bahaya dan tuntutan seperti: sedikit pengaruh pada kondisi kerja; tidak ada pengaruh pada urutan pekerjaan tugas yang dilakukan; kurangnya kontrol atas kondisi kerja; kurangnya informasi dan keterlibatan dalam isu-isu yang lebih luas yang mempengaruhi organisasi dan pekerjaan mereka; kurangnya dukungan sosial dari para manajer (Zock, 2005).

Buruh perempuan merupakan salah satu komunitas yang rentan terhadap masalah kesehatan. Buruh perempuan yang telah menikah dan punya anak memiliki peran dan tanggung jawab yang lebih berat daripada wanita single. Peran ganda pun dialami oleh wanita tersebut karena selain berperan di dalam keluarga, wanita tersebut juga berperan di dalam karirnya. Konflik pekerjaan-keluarga menjelaskan terjadinya benturan antara tanggung jawab pekerjaan di rumah atau kehidupan rumah tangga sehingga dapat berakibat kepada kesehatan pekerja tersebut (Frone dkk., 1994).

Riset yang dilakukan oleh Health and Safety Executive Inggris menyebutkan bahwa wanita dengan rentang usia 25 sampai 54 terbukti lebih mudah tertekan terkait pekerjaan dari pada pria. Tapi pekerja yang berumur 35 hingga 44 lah adalah yang paling stres di antara mereka. Penyebabnya adalah kesulitan menyeimbangkan tugas sebagai seorang karyawan, ibu, dan anak. Para wanita yang berusia matang ternyata mengalami kendala saat mengurus anak dan menjaga orangtua sambil berkarier dalam waktu bersamaan. Penelitian yang dilakukan oleh Oktarina (2015) mendapatkan hasil bahwa faktor yang mempengaruhi tingkat kesehatan buruh perempuan adalah pendapatan per kapita, sumber stress di tempat kerja dan strategi koping fokus emosi (Oktarina dan Krisnatuti, 2015).

Pabrik karet di Sumatera Selatan mempekerjakan banyak buruh wanita yang mayoritas berdomisili di seputar pabrik sebagai tenaga kerja. Status buruh yang tidak memiliki ketetapan dalam bekerja dapat berisiko menimbulkan bahaya psikosial di tempat kerja. Berdasarkan uraian mengenai bahaya psikososial yang mengintai kesehatan para pekerja buruh wanita maka penting untuk dilakukan penelitian mengenai bahaya psiososial pada pekerja buruh wanita di tempat kerja. Tujuan penelitian untuk melakukan identifikasi terhadap hazard psikososial pada pekerja buruh di tempat kerja. 


\section{METODE PENELITIAN}

Metode penelitian dalam penelitian ini adalah studi kualitatif. Penelitian kualitatif menggunakan metode kualitatif yaitu pengamatan (observasi lapangan), wawancara mendalam, atau penelaahan dokumen. Metode kualitatif digunakan untuk memahami fenomena tentang apa yang dialami oleh subjek penelitian secara holistik, dan dengan cara deskripsi dalam bentuk kata-kata dan bahasa. Dalam penelitian ini yang menjadi informan terdiri dari delapan orang buruh wanita di Kota Palembang yang dipilih secara purposif.

\section{HASIL DAN PEMBAHASAN}

Menurut UU No 13 Tahun 2003 Bab 1 Pasal 1 atau 2, tenaga kerja adalah setiap orang yang mampu melakukan pekerjaan guna menghasilkan barang dan atau jasa baik untuk memenuhi kebutuhan sendiri maupun untuk masyarakat. Tenaga kerja merupakan modal utama serta pelaksanaan dari pembangunan masyarakat pancasila. Tujuan terpenting dari pembangunan masyarakat tersebut adalah kesejahteraan rakyat termasuk tenaga kerja. Tenaga kerja sebagai pelaksana pembangunan harus di jamin hak-haknya.

PER-03/MEN/1994

mengatakan bahwa pengertian tenaga kerja adalah setiap orang yang bekerja pada perusahaan yang belum wajib mengikuti program jaminan sosial tenaga kerja karena adanya pentahapan kepesertaan.

Secara umum pengertian buruh adalah orang yang bekerja untuk orang lain dengan mendapatkan upah. Dalam konteks kepentingan didalam suatu perusahaan terdspat dua kelompok yaitu kelompok pemilik modal (owner) dan kelompok buruh, yaitu orang-orang yang diperintah dan dipekerjakan dan berfungsi sebagai salah satu komponen dalam proses produksi. Dalam teori Karl Marx tentang nilai lebih disebutkan bahwa kelompok yang memiliki dan menikmati nilai lebih disebut sebagai majikan dan kelompok yang terlibat dalam proses penciptaan nilai lebih itu disebut buruh.

Bahaya psikososial adalah suatu bahaya non fisik yang timbul karena adanya interaksi dari aspek-aspek pekerjaan seperti desain kerja, tuntutan kerja, organisasi dan manajemen di tempat kerja serta konteks lingkungan sosial yang berpotensi menimbulkan gangguan bagi kesehatan para pekerja secara fisik, sosial dan psikologi. Bahaya psikososial dapat disimpulkan menjadi beberapa aspek berdasarkan kategori karakteristik kerja, organisasi dan lingkungan kerja dimana dapat menyebabkan gangguan kesehatan. Hal ini menunjukkan bahwa karakteristik kerja dapat digunakan untuk menggambarkan bahaya kaitannya dengan hubungan kerja atau isi dari pekerjaan. Kondisi yang tak pasti dari aspek kerja dapat menimbulkan stress dan berbahaya bagi kesehatan. Banyak dari berbagai kejadian penyakit berhubungan dengan psikologi kesehatan dan berisiko terkena penyakit jantung.

Berikut adalah bahaya psikososial yang teridentifikasi di pabrik karet Sumatera Selatan:

\section{Hubungan Interpersonal}

Hubungan interpersonal adalah hubungan yang terdiri atas dua orang atau lebih yang memiliki ketergantungan satu sama lain dan menggunakan pola interaksi yang konsisten, ketika akan menjalin hubungan interpersonal akan terdapat suatu proses yang dimulai dengan interpersonal atraction. Pada perusahaan karet, hubungan interpersonal berupa hubungan dengan sesama rekan kerja dan hubungan antara pimpinan maupun perusahaan dan dukungan yang diberikan oleh sesama pekerja ataupun dukungan 
dari atasan apabila terdapat perselisihan ialah perselisihan antar sesama karyawan maupun perusahaan kemungkinan terjadi sering, hal ini sama dengan informasi yang disampaikan oleh informan saat dilakukan wawancara mendalam sebagai berikut :

“...Kalo selisih tu ado la eh kalo samo atasan dak pernah... Yo mandor galak cari pemecahanyo.." (KL)

“...Yo namonyo begawe la lamo aman dak pernah selisih yo dak mungkin la... Aman selisih yo mandor biasonyo yang bantuin nengahke cari penyelesaiannyo..." (DW)

“...Baik-baik bae kalo dengan sesamo buruh eeh kalo samo mandor krani tu baik jugo tapi yo Cuma kadang ado masalah bayaran ini tu la, kan galak lebih jam kerjo tu ado dak dibayar... Yo sesamo buruh ni yang galak protes gek saling bantu ngomong ke dengan pimpinan tu tapi mencak nak demo yo idak jugo..." (RD)

“...Kalo bagi aku dak katek dak pernah, kalo cekcok dikit-dikit tu yo pasti ado lah... Dak ado yang bantuin yo kagekkan baikan dewek kelang berapo hari..." (NZ)

"...Itu nak nyato nian apo idak? kalo nyato nian sekarang ni ado permasalahan samo atasan samo perusahaan, ado masalah selisih jam kerja. Pacak jago rahasio dak ini? jadi kan kelebihan jam kito ni, nah kelebihan jamnyo itu dak dibayar jadi ekarang ni kito masih nuntut, dalam seminggu tu lebih 8 jam... Pernah diselesaike samo mandor..." (IC)

"...Baik, dak ado masalah dak ado... Yo saling curhat kagek di kasih saran..." (WT)

"...Hubungan samo kawan begawe yo baik samo mandor yo baek jugo... Kalo sulit pas begawe yo dibantuin, tapi kalo tentang selisih cak itu alhamdulillah aku dak pernah..." (LW)

\section{Beban Kerja}

Beban kerja adalah frekuensi kegiatan rata-rata dari masing-masing pekerjaan dalam jangka waktu tertentu berupa tambahan jam kerja diluar jam kerja atau lembur kerja tuntutan waktu saat bekerja. Pada perusahaan karet, beban kerja berupa lembur kerja dan tuntutan waktu saat bekerja ialah sering terjadi disemua situasi dan menimbulkan kerugian materi yang cukup tinggi dikarenakan pekerja buruh tidak dibaya upah lemburnya, hal ini sama dengan informasi yang disampaikan oleh informan saat dilakukan wawancara mendalam sebagai berikut :

“...Yo kalo lagi banyak kontrak paling lembur 2 jam kan atau dak lebih... Galak yo, disini kan borongan ni, jadi kalo dio lambat yo hasilnyo kecik, iyo harus cepet..." (KL)

“...Sering jugo kalo lembur... Iyo kadang Cuma diomong jangan galak ngobrol bae waktu begawe, jangan lelet itu bae, tapi men nak cepat dak biso soalnyo kan diover ado ditentuin waktunyo berapo timernyo cak itu..." (DW)

“...Lembur sering, tapi kalo sekarang lagi kosong bahan ni balek dak ado jugo lembur... Katek men tuntutan diminta cepat-cepat tu..." (RD)

'...Yo kalu tempo hari yo sering tapi sekarang dak ado lagi... Iyo pernah iyo, kami jugo dak pacak nak cepet-cepet karno jago mutu jugo, kalo hasil cepat tapi mutunyo jelek kan..." (NZ)

"...Sering, kalo biasonyo banyak karet itu yo kito full biso balek sampe jam 18.00 , kadang jugo smpe jam 20.00 Cuma agak jarang, minggunyo jugo kalo lagi lancar yo lembur, tapi itu la yang cak aku omong tadi kalo sekarang ni lagi masalah dak dibayar ke duitnyo itu... Ado jugo tapi dak biso cepet karno ado tahapannyo la..." (IC)

“...Dak jugo sering kalo bulan- bulan ini, iyo karno karetnyo lagi dikitkan dak 
lembur... Iyo cepet kalo nak kejer borongan ini lah..." (WT)

“...Iyo lumayan sering kalo lembur... Idak ado kalo disuruh cepat-cepat...” ( $L W)$

Dalam pandangan keselamatan dan kesehatan kerja, lingkungan kerja dapat merupakan tempat berisiko bagi tenaga kerja untuk mengalami gangguan kesehatan atau mengalami kecelakaan kerja. Dari bahaya tersebut risiko terpajan bahaya psikososial dapat dipastikan akan dihadapi oleh seluruh tenaga kerja yang dapat menimbulkan stres kerja dan menjadi masalah bagi kesehatan dan keselamatan kerja. Penelitian pendahuluan di Barcelona menemukan bahwa pekerja wanita yang tidak berpendidikan memiliki status kesehatan yang lebih buruk daripada pekerja wanita yang berpendidikan (Borrell dkk., 2004). Risiko psikososial berdasarkan penelitian Ruliati (2006) dipengaruhi oleh kelelahan kerja yang dapat mengakibatkan stress kerja.

Hubungan interpersonal merupakan bahaya yang teridentifikasi pada buruh di pabrik karet. Hal ini sejalan dengan penelitian Rohmana (2016) tentang gambaran faktor psikososial di tempat kerja pada pekerja tekstil PT. Sandratex tahun 2016, yang menemukan bahwa variabel hubungan interpersonal antara sesama pekerja ataupun pekerja dengan pimpinan diketahui bahwa 56,4\% responden menilai bahwa terdapat hubungan yang buruk antara sesama pekerja ataupun pimpinan dan kurangnya komunikasi antar pihak pekerja dengan manajemen. dan berdasarkan penelitian Sukmawati tentang persepsi bahaya psikososial kerja dan hubungan dengan tingkat stres pada tenaga medis di kota Pekanbaru menemukan bahwa $61,8 \%$ merasakan hubungan interpersonal sebagai bahaya sedang dan mengalami tingkat stres sedang.

Kondisi faktor hubungan interpersonal dan kepemimpinan yang buruk dapat berdampak pada beberapa masalah kesehatan. Beberapa hasil penelitian menunjukkan bahwa kondisi dukungan sosial yang rendah dapat berpengaruh terhadap peningkatan risiko masalah kesehatan seperti stres, gangguan kardiovaskuler, penyakit jantung koroner, gangguan mental yang umum, depresi, serta sakit leher. Untuk menjaga kualitas iklim sosial di tempat kerja biasanya didukung oleh adanya dukungan sosial dari rekan kerja melalui beberapa pertemuan dan kebersamaan yang menyenangkan (Eurofound, 2012).

Faktor bahaya psikososial beban kerja juga termasuk risiko yang menimbulkan kerugian materi karena pekerja merasa dirugikan dengan upah pengganti lembur kerja yang tidak dibayarkan oleh perusahaan. Hal ini sejalan dengan penelitian Ricky (2012) yang menemukan bahwa variabel beban kerja yang meliputi pandangan subjektif responden terhadap besaran pekerjaan yang dilakukan dan waktu yang diberikan untuk menyelesaikannya diketahui bahwa $66,1 \%$ responden menilai pekerjaan yang dilakukan merupakan pekerjaan yang memiliki beban kerja yang berat.

Menurut French dkk. (1974) dalam Cox dkk. (2000), beban kerja dapat dibagi dua, yakni beban kerja secara kualitatif dan beban kerja secara kuantitatif. Beban kerja kuantitatif dilihat berdasarkan tingkat kesulitan yang dihadapi pekerja dalam menyelesaikan pekerjaannya, sedangkan beban kerja kualitatif berdasarkan banyaknya tugas yang harus diselesaikan pekerja. Beban kerja buruh di pabrik karet cenderung memiliki beban kerja secara kualitatif, hal ini dapat dilihat dari tuntutan waktu pekerjaan untuk melakukan pekerjaan dengan cepat dan tambahan waktu kerja atau lembur kerja yang hampir terjadi setiap hari, serta adanya beban kerja secara kuantitatif juga dirasakan oleh pekerja seperti tingkat 
kesulitan yang dihadapi pekerja dalam menyelesaikan pekerjaannya.

\section{KESIMPULAN}

Berdasarkan hasil penelitian yang telah dilakukan pada delapan informan diketahui bahwa bahaya psikososial yang teridentifikasi pada pekerja buruh wanita di pabrik karet kota Palembang diantaranya adalah adalah risiko stress di tempat kerja berupa hubungan interpersonal dan beban kerja.

\section{UCAPAN TERIMA KASIH}

Pada kesempatan ini penulis mengucapkan terima kasih kepada Lembaga Penelitian Universitas Sriwijaya yang telah mendukung dan mendanai sehingga penelitian ini dapat terlaksana.

\section{DAFTAR PUSTAKA}

Borrell, C., Muntaner, C., Benach, J., Artazcoz, L. (2004). Social class and self-reported health status among men and women: what is the role of work organisation, household material standards and household labour?, Social Science \& Medicine, 58(10), pp. 1869-1887. doi: https://doi.org/10.1016/S02779536(03)00408-8.

Eurofound. (2012). Health and Well-being at Work: A Report Based on the Fifth European Working Conditions Survey. Dublin.

Frone, M.R, Russel, M \& Cooper, M. (1994). Relationship between Job and Family Satisfaction, Journal of Management, 20, pp. 565-579.

Haribi, R. (2003). Kadar Haemoglobin pada Buruh Wanita yang Bekerja Malam Hari, Jurnal Litbang Universitas Muhammadiyah Semarang. Vol 1, No 1.

International Labour Organization. (2018). Promoting Jobs, Protecting People. Available at: http://www.ilo.org/global/topics/safety-and-health-at-work/lang-en/index.htm. Diakses tanggal 2 Februari 2018.

Landsbergis, P. A. (2003). The Changing Organization of Work and the Safety and Health of Working People: A Commentary, Journal of Occupational and Environmental Medicine, 45(1). Available at: https://journals.lww.com/joem/Fulltext/2003/01000/The_Changing_Organizati on of Work_and the Safety.14.aspx.

MIL STD 882C. (1993). Military Standard System Safety Program Requirements, in. Department of Defense, United States of America. Available at: http://www.system-safety.org/Documents/MIL-STD-882C.pdf. 20 Februari 2018.

Moleong, L. (2010). Metodologi Penelitian Kualitatif Edisi Revisi. PT. Remaja Rosda karya, Bandung.

NIOSH. (2013). Health Hazard Evaluation Report. Available at: http://www.cdc.gov/niosh/hhe/reports/pdfs/2012-0081-3169.pdf. 2 Februari 2018.

Oktarina, R. \& Krisnatuti, D. I. M. (2015). Sumber Stress, Strategi Koping, dan Tingkat Stress pada Buruh Perempuan Berstatus Menikah dan Lajang, Jurnal Ilmu Keluarga dan Konsumen, 8(3), pp. 133-141.

Pratama, Ricky. (2012). Studi Bahaya Psikososial terhadap Stress Kerja pada Petugas Pemadam Kebakaran Kota Depok. Fakultas Kesehatan Masyarakat. Universitas Sriwijaya. 
Rockefeller. (2013). Health Vulnerabilities of Informal Workers, in Innovation for The Next 1000 years, p. 4.

Toukas, D., Delichas, M., Toufekoula, C., Spyrouli, A. (2015). The Role of Labour Inspectorates in Tackling the Psychosocial Risks at Work in Europe: Problems and Perspectives, Safety and Health at Work, 6(4), pp. 263-267. doi: https://doi.org/10.1016/j.shaw.2015.06.001.

Zock, J.P. (2005). 'World at Work', Occupational and Environmental Medicine, 6, pp. $581-584$. 